\title{
Adjective Distribution in Mongolian and Japanese
}

\author{
Wenchao Li \\ Department of Japanese Study, Zhejiang University, China
}

Copyright $\odot 2017$ by authors, all rights reserved. Authors agree that this article remains permanently open access under the terms of the Creative Commons Attribution License 4.0 International License

\begin{abstract}
This paper tackles how adjectives distribute in Mongolian and Japanese in light of the framework 'scale structure'. It is explicated that Mongolian resultatives are of three types, i.e. adjective-post resultative; adjective-initial resultative; co-verb resultative. The acceptability of adjectival complements in inherent resultatives runs from 'Totally open-scale AP' down to 'Lower closed-scale AP, Upper-closed scale AP, Totally closed-scale AP'. Mongolian welcomes all layers of adjectives in direct perception expressions. Japanese adjectives are re-categorised into two types, i.e. open-scale adjectives (corresponding to the traditional $i$-adjective) and closed-scale adjectives (corresponding to the traditional $n a$-adjective). Though both are capable of rendering an inherent result, the resultatives rendered by open-scale adjectives and closed-scale adjectives present different lexicalisation patterns. Moreover, like Mongolian, derived resultatives are also missing in Japanese. The lack of derived resultatives in Altaic languages is down to the following reason, i.e. Altaic languages are likely to lexicalise the RESULT into the MAIN VERB. In inherent resultatives, there is a connection between CAUSE EVENT and RESULT EVENT, i.e. the verb carries an implication of result. In derived resultatives, a GAP arises between ACTION and RESULT. Regarding direct perception expressions, Japanese seems to welcome both open-scale and closed-scale APs. The perceptual verb 見る miru solely delivers the perceived event and is thus deemed objective. 見える mieru, on the other hand, cannot fulfil a metaphorical interpretation, and appears to be subjective.
\end{abstract}

Keywords Scale Structure, Adjectives, Mongolian, Japanese

\section{Introduction}

Mongolian, an Altaic language, is deemed an exclusively suffixing agglutinative SOP language. Seven cases are mostly used: nominative, accusative, genitive, dative-locative, ablative, instrumental, and comitative. A salient feature of Modern Mongolian lies in the fact that adjectival complements may directly precede the verbs, as seen in the resultative construction (1).

$$
\begin{aligned}
& \text { (1). Тэр ханаа улаан/улаанаар будсан. } \\
& \text { she wall red/red. INSTR paint-PAST } \\
& \text { 'She painted the wall red.' }
\end{aligned}
$$

In terms of resultative constructions, two grammatical elements seem capable to indicate result, i.e. adjective and co-verb, which give rise to three types of resultative constructions: (i). adjective-post type $\left[\mathrm{NP}_{1} \mathrm{VNP}_{2} \mathrm{AP}\right](2 \mathrm{a})$; (ii). adjective-initial type $\left[\mathrm{NP}_{1} \mathrm{AP} \mathrm{V} \mathrm{NP}_{2}\right]$ (2b); (iii) co-verb type $\left[\mathrm{NP}_{1} \mathrm{~V} \mathrm{~V} \mathrm{NP}_{2}\right](2 \mathrm{c})$.

(2). Mongolian resultative construction types

$$
\begin{aligned}
& \text { a. Adjective-post type }\left[\mathbf{N P}_{\mathbf{1}} \mathbf{V N P}_{\mathbf{2}} \mathrm{AP}\right] \\
& \text { Тэр эрэгтэй төмөр таяг дабдажъ } \\
& \text { DEM } 1^{\text {st }} \cdot \text { masc.sg metal stick pound } \\
& \text { урт болгаб. } \\
& \text { long PAST } \\
& \text { 'He pounded the metal long.' }
\end{aligned}
$$

\section{b. Adjective-initial type $\left[\mathbf{N P}_{\mathbf{1}} \mathbf{A P V} \mathbf{N P}_{2}\right]$}

$$
\begin{array}{llcll}
\text { Тэр } & \text { эрэгтэй } & \text { гутлаa } & \text { цоортол } & \text { өмссөн. } \\
\text { DEM } & 1^{\text {st }} \text {.masc.sg } & \text { shoe } & \text { broken } & \text { wear-PAST }
\end{array}
$$$$
\text { 'He wore the shoe (until) it is broken.' }
$$

\section{c. Co-verb type $\left[\mathrm{NP}_{\mathbf{1}} \mathrm{V} V \mathrm{NP}_{\mathbf{2}}\right]$}

Тэр эрэгтэй үсээнбййрэн бичиж байгаад хугалсан. DEM $1^{\text {st }}$.masc.sg pen write-break-PAST

'He writes with the pen (until it is) broken.'

In Mongolian resultatives, one issue that is particularly worthy of discussion is that not all adjectives seem capable of indicating a RESULT. In ( $1 \mathrm{~b}$ ), the adjective улаан ('red') is tolerated; while the following adjective, xamyy ('solid') is ruled out.

$$
\begin{array}{llll}
\text { (3). *Нуyр } \quad \begin{array}{cl}
\text { хатуу_биет } \\
\text { lake }
\end{array} \text { solid } & \text { хөлджээ. } & \text { (ill-formed) } \\
\text { 'The lake froze solid.' } & &
\end{array}
$$

The different treatments of (1) and (3) are probably down to the resultative construction type as well as the scalar property of adjectives (i.e. adjective xamyy 'solid' is a closed-scale AP whilst улаан 'red' is open-scale). 
Moving on to Japanese, another deemed Altaic language, RESULT can be rendered via three grammatical elements: (i) a PP (4); (ii) a verb compound, where the change of state is potentially conflated into the main verb (5); and (iii) an AP (6):

(4). Prepositional phrase

$\begin{array}{llrll}\text { Madogarasu } & \text { o } & \text { konagona } & \text { ni } & \text { watta. } \\ \text { Window } & \text { ACC } & \text { pieces } & \text { into } & \text { break.PAST }\end{array}$

'Break the window into pieces.'

(5). Compound verb

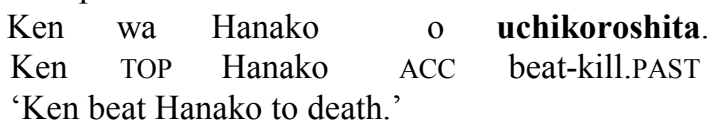

(6). Adjectival complement

Ken wa gomu o nagaku nobashita. Ken TOP rubber ACC long stretch.PAST 'Ken stretched the rubber long.'

This study intends to explore the distribution of APs; therefore, only constructions like (6) will be tackled.

Regarding Japanese adjectives, traditional linguists consider them as falling into two groups, i.e. $i$-adjectives (7) and $n a$-adjectives (8).

(7). ( $i$-adjective)

Hanako wa kabe o shiroku nutta. Hanako TOP wall ACC white paint. PAST 'Hanako painted the wall white.'

(8). (na-adjective)

Hanako wa kabe o masshiro ni nutta. Hanako TOP wall ACC completely COP paint. PAST 'Hanako painted the wall completely white.'

It appears that both the $i$-adjective and $n a$-adjective are allowed to indicate a result in Japanese resultatives.

Furthermore, unlike English resultatives, where open-scale APs are ruled out (c.f. 9a), ${ }^{1}$ and Japanese licenses open-scale APs, as in (9b):

$$
\text { a. Open-scale APs in English resultatives: }
$$
*Taroo stretched the rubber long.

b. Open-scale Aps in Japanese resultatives: Taroo wa gomu o nagaku nobashita.

It appears that the two languages have the undeniable similarities in favouring open-scale adjective as resultative complements. This is a preliminary illustration that inspires us to investigate adjective distribution in more depth.

This paper is mapped out as follows. Section 2 sheds light on the framework 'lexical conceptual structure' and 'scale structure'. Section 3 categorises Mongolian resultative construction types, then examines the acceptability of adjectival complement. Next, it tackles the distribution of adjectives in direct perception expressions. Section 4 delves into the question of how adjectives are treated in Japanese.
Section 5 highlights the results and concludes the paper.

\section{Framework}

To set the stage for resultative and direct perception construction, we sketch an overview of previous studies on resultatives. The discussions referred to below focus on resultative constructions, which have long been an important issue in linguistic typological work.

For the past half century, various frameworks have been proposed to achieve a thorough analysis on resultatives. In earlier times, analysis focuses upon the syntactic perspective, representative work includes Chomsky's (1965) 'Aspects Model', Levin and Rappaport Hovav's (1995) 'Projection Approach'. However, this approach appears unable to explain why the unergative verb laugh can appear in both 'Mary laughed herself sick' and 'The audience laughed the actors off the stage'. Therefore, later on, a different view, i.e. 'Construction Grammar Approach' was provided by Goldberg (1995). This pioneering attempt has had a significant influence on the study of resultatives and is welcomed among linguists, e.g. Jackendoff's (1997) 'Adjunct Analysis', Rappaport Hovav \& Levin's (1998) 'Event Structure Template', and Boas's (2003) 'Dynamic Usage-Based Model'. In the late 1990s, the locus of cross-linguistic diversity transited from syntactic representation to resultative predicates (Vanden Wyngaerd 2001, Boas 2000, Wechsler 2005, etc). Among them, the Japanese linguist Kageyama's (1996, 1999) work is noteworthy. Kageyama classifies the resultative constructions into two types, i.e. inherent resultatives vs. derived resultatives. He gives the Lexical Conceptual Structure (LCS) of each type as follows.

(10). a. [ x ACT-ON y] CAUSE [y BECOME [BE-AT z]] (inherent resultatives)

b. [ x ACT-ON y] (derived resultatives)

A clear illustration of inherent resultatives and derived resultatives is given below.

(11). Inherent resultatives

a. Bill wiped the table clean.

b. Bill wa teiburu o kirei ni fuita. Bill TOP table ACC clean ${ }_{\mathrm{COP}}$ wipe.PAST

(12). Derived resultatives

a. Sam kicked Bill black and blue.

*Sam wa Bill o aza darake ni ketta.

Sam TOP Bill ACC blue PART COP kick.PAST 
Table 1. Mongolian Cyrillic alphabet

\begin{tabular}{|c|c|c|c|c|c|c|c|c|c|c|c|}
\hline а $a$ & б $b$ & в $v$ & г $g$ & д $d$ & е $y e$ & ё $y o$ & ж $j$ & з $d z$ & и $i$ & й $y$ & к $k$ \\
\hline л $l$ & м $m$ & н $n$ & о $o$ & ө $\ddot{o}$ & п $p$ & $\mathrm{p} r$ & с $s$ & т $t$ & у $u$ & ү $\ddot{u}$ & ф $f$ \\
\hline х $k h$ & ц $t s$ & ч $c h$ & ш $s h$ & щ shch & ь $”$ & ы $i$ & ь & э $e$ & ю $y u$ & я $y a$ & \\
\hline
\end{tabular}

It is pointed out that in inherent resultatives; the result of the theme is implied by the main verbs. For instance, 'wipe' may possibly give rise to the result of 'clean'.

In fact, Kageyama was not the first to classify the type of resultative construction. Many scholars have made similar proposals. For instance, Kageyama (1996) labels the two constructions as 'inherent resultatives' vs. 'derived resultatives'; Washio (1997) refers to them as 'strong resultatives' vs. 'weak resultatives'; Iwata (2006) employs the terms 'argument resultatives' vs. 'adjunct resultatives'; and in Levin \& Rappaport Hovav (1995) and Kennedy's (1999) works, 'control resultatives' vs. 'exceptional case-marking resultatives' is used. Moreover, Dimitrova-Vulchanova (2002) employs 'connected resultatives' vs. 'disconnected resultatives' to describe resultatives. All these terms differ slightly but ultimately refer to the same thing. The current paper follows Kageyama's (1996) terminology, i.e. 'inherent resultatives' vs. 'derived resultatives'.

In addition, three writing systems exist in Modern Mongolian, i.e. Todo Bicig (Xinjiang area), Traditional Mongolian alphabet (Hudum) (Inner Mongolia) and Cyrillic Mongolian (Outer Mongolia). This study adopts Cyrillic Mongolian writing. Table 1 provides a list of Mongolian Cyrillic alphabet.

In terms of the data, hand-made examples are used. Native speakers checked the examples. Due to numerous dialects in the country, native speakers from the Inner and Outer parts of Mongolia have both been asked to provide judgements. Moreover, a multilingual parallel electronic dictionary is employed: http://asuult.net/dic/.

The data for Japanese is drawn from the corpus of Balanced Corpus of Modern Written Japanese by National Institute for Japanese language and linguistics.

\section{Adjective Distribution in Mongolian}

This section begins by looking into the scalar property of Mongolian APs, and their distributions in resultative and direct perception expressions.

\subsection{Mongolian Resultative Constructions}

As touched upon earlier, Mongolian resultatives are of three types. (i) the adjective-post type $\left[\mathrm{NP}_{1} \mathrm{VNP}_{2} \mathrm{AP}\right]$; (ii) the adjective-initial type $\left[\mathrm{NP}_{1} \mathrm{AP} \mathrm{V} \mathrm{NP}_{2}\right]$; and (iii) the co-verb type $\left[\mathrm{NP}_{1} \mathrm{~V} \mathrm{~V} \mathrm{NP} \mathrm{N}_{2}\right]$. Before looking into how adjectives distribute in these types, it would be necessary to shed light on the syntactic features of the types.
First, adjective-post resultatives display the following variations: transitive resultatives $\left[\mathrm{NP}_{1} \mathrm{~V}_{\mathrm{t}} \mathrm{NP}_{2} \mathrm{AP}\right]$, as in (13); and intransitive resultatives $\left[\mathrm{NP}_{1} \mathrm{~V}_{\mathrm{i}} \mathrm{NP}_{2} \mathrm{AP}\right]$, as in (14).

(13). Transitive resultatives $\left[\mathrm{NP}_{1} \mathrm{~V}_{\mathrm{t}} \mathrm{NP}_{2} \mathrm{AP}\right]$

$$
\begin{array}{llccc}
\text { Тэр } & \text { эрэгтэй } & \text { төмөр } & \text { таяг } & \text { дабдажъ } \\
\text { DEM } & 1^{\text {st }} . \text { masc.sg } & \text { metal } & \text { stick } & \text { роund } \\
\text { урт } & \text { болгаб. } & & & \\
\text { long } & \text { PAST } & &
\end{array}
$$

(14) Intransitive resultatives $\left[\mathrm{NP}_{1} \mathrm{~V}_{\mathrm{i}} \mathrm{NP}_{2} \mathrm{AP}\right]$

$\begin{array}{lccr}\text { Тэр } & \text { эрэгтэй } & \text { өрөөн } & \text { иниесээр } \\ \text { DEM } 1^{\text {st }} \text {.masc.sg } & \text { himself } & \text { laugh } \\ \text { байжъ } & \text { Өбчитай } & \text { болоб. } & \\ \text { PROG } & \text { sick } & \text { PAST } & \end{array}$

'He laughed himself sick.'

Note that in intransitive resultatives, when an unaccusative verb denotes the action verb, the CHANGE-OF-STATE EVENT becomes spontaneous, which leads to an anticausativisation phenomenon. ${ }^{2}$ When an unergative verb renders the action verb, the CHANGE-OF-STATE EVENT becomes intentional, giving rise to decausativisation.

We now turn to adjective-post resultatives $\left[\mathrm{NP}_{1} \mathrm{~V} \mathrm{NP}{ }_{2}\right.$ $\mathrm{AP}]$, as illustrated in (15). Six Mongolians from different areas provided the judgement.

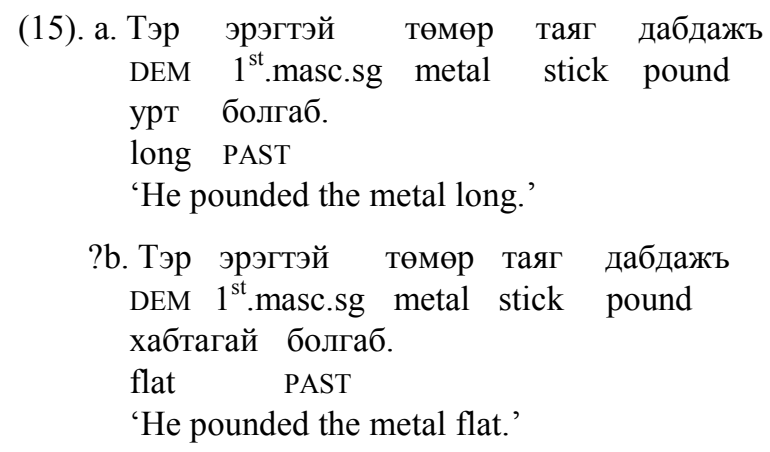

2 The terms anticausativisation and decausativisation were initially coined by Japanese linguist Kageyama Taro (1996). He defines the them as follows: a. Anticausativisation

The CHANGE-OF-STATE is brought about by the patient itself, therefore the agent and the patient can be identified.

b. Decausativisation

The CHANGE-OF-STATE is brought about by external facts. Syntactically, the agent is suppressed and thus is not projected onto the syntactic structure. 
c. Тэр эрэгтэй ль сийг сажилажъ сэргээб. DEM $1^{\text {st }}$.masc.sg Lisi shake awake-PAST 'He shook Lisi awake.'

?d. Тэр эрэгтэй өбөст газар усулжъ чийг болгаб. DEM $1^{\text {st }} \cdot$ masc.sg garden water wet PAST 'He watered the garden wet.'

(15a) and (15c) are judged natural, whereas (15b) and (15d) are deemed to be unnatural. If, however, the adverbial, i.e. жинхэнэ ('very'), is supplied to the adjectives хабтагай ('flat') and азчий ('wet'), the odd expressions (15b) and (15d) can be improved:

(16). а. Тэр эрэгтэй төмөр таяг дабдажъ жинхэнэ хабтагай болгаб. (natural)

b. Тэр эрэгтэй өбөст газар усулжъ жинхэнэ чийг болгаб.
Why, then, are the above adjective-post resultatives treated differently? We analysed the 'lexical conceptual structure' and found that each construction displays the following distinction (17 represents $15 \mathrm{a}$ and $15 \mathrm{c} ; 18$ represents $15 \mathrm{~b}$ and $15 \mathrm{~d})$ :

(17). LCS of (15a) and (15c)

$\left[\begin{array}{lll}x & \text { act }- \text { on } & y\end{array}\right]$ cause $[y$ become [be-at z]]

(18). LCS of (15b) and (15d)

$\left[\begin{array}{lll}x & \text { act }- \text { on } & y\end{array}\right]$ cause $[y$ become [be-at z] $]$

The CAUSE EVENT of (15a) and (15c) may directly result in the RESULT EVENT. Moreover, the CAUSE and the RESULT are associated (i.e. CONTROL). (15a) can be described as follows:

Accomplishment (Тэр эрэгтэй төмөр таяг дабдажъ урт болгаб)

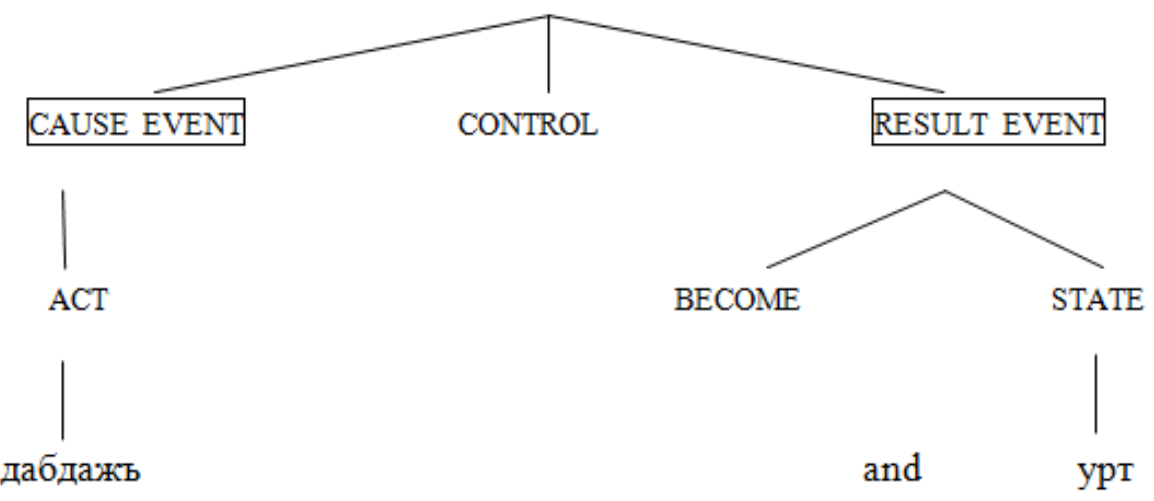


On the other hand, the CAUSE and the RESULT in (15b) and (15d) are not associated. To put it another way, there is a gap between the CAUSE and the RESULT. Intriguingly, by supplementing the adverb жинхэнэ ('very') to the ill-formed expressions (15b) and (15d), the oddness of the phrasing can be reduced. This is because the extra adverb жинхэнэ ('very') temporarily fills the GAP between the CAUSE and the RESULT at a syntactic level; and because the syntactic supplement semantically draws the connection between the CAUSE EVENT and the RESULT EVENT. The process is described in (19).

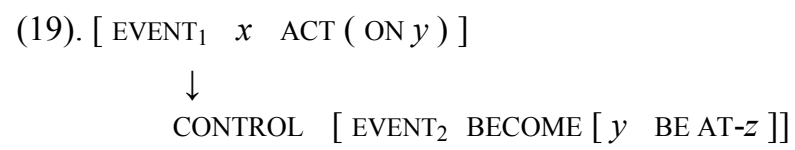

Furthermore, following Kageyama (1996), resultatives like (15a) and (15c) are 'inherent resultatives'; (15b) and (15d) are 'derived resultatives'. Keeping this in mind, it appears that 'derived resultatives' are missing in Mongolian. There are three ways to express a derived resultative: (a) to employ an adverb (e.g. жинхэнэ) to temporarily fill the GAP between CAUSE EVENT and RESULT EVENT; (b) to go for a co-verb construction, as in (20); or (c) to use a postpositional phrase, as in (21).

(20). Derived resultatives, denoted by a co-verb construction:

Тэр эмэгтэй уйлаад л байсан.

dem 1st.femi.sg cry-prog-tired-past
'She cried (until she got) tired.'

(21). Derived resultatives denoted by a postpositional phrase:

Тэр эрэгтэй ус хөлдөөж мөс болгов. dem 1st.masc.sg water freeze solid become 'He froze the water, and the water turned into ice.'

Another member of the Altaic language family, Japanese, also seems to lack derived resultatives, as shown in (22).

(22). a. Inherent resultatives $\begin{array}{llll}\text { 太郎は } & \text { 壁をを白く } & \text { 塗った。 } \\ \text { Taro wa kabe o siroku nutta. } & \text { nate } \\ \text { Taroo TOP wall ACC white } & \text { paint-past } \\ \text { 'Taro painted the wall white.' } & \end{array}$

b. Derived resultatives (ill-formed) *彼女は魚をゼリ一状に吒いた。 Kanojo wa sakana o zerii joo ni tataita. She TOP fish ACC jelly COP pound-past 'She pounded the fish into a jelly.'

The lack of derived resultatives in the Altaic language family is possibly because Altaic languages tend to lexicalise the RESULT into the MAIN VERB. To put it another way, the CONTROL part of LCS carries an implication of $z$. For instance, in (22a), the verb 塗る nuru ('paint') implies the RESULT: ‘壁が白くなる: the wall turns white’. The LCS for $(22 \mathrm{a})$ is:

(23). [x ACT ON y]CAUSE $[y$ BECOME $[y$ BE AT- $z]]$

(CONTROL canies an implication of $z$ )

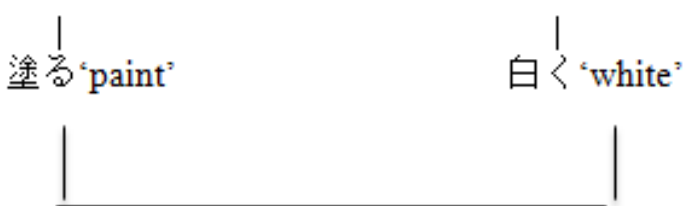


Essentially, in (23), there is a connection between the CAUSE EVENT [ $\left[\mathrm{EVENT}_{1} \quad \mathrm{x}\right.$ ACT $\mathrm{ON} \quad y$ ] and the RESULT EVENT [EVENT 2 y

In (22b), the ACTION 吒< ('tataku pound') fails to lead directly to the RESULT: ' $y$ がゼリ一状になる (the fish turns into jelly)'. Thus, a GAP arises between the ACTION and the RESULT.

(24).
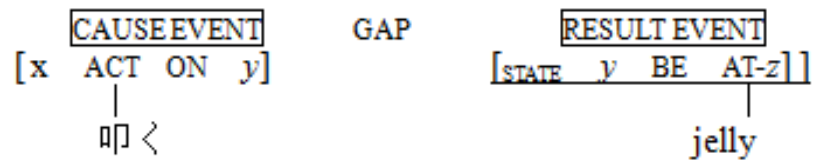

One way to solve the problem is to employ an adverbial, and thus temporarily fill the gap. For LCS, this manipulation would be:

(25) [event1 $\mathrm{x}$ act on $y$ ] cause $_{1}$ [event2 $y$ become [change-of-state]] cause ${ }_{2}$ [STATE $y$ be at- $z_{2}$ ]

Another issue worthy of discussion regarding adjective-post resultatives is the phenomenon of decausativisation, c.f. (26):

\section{(26). Тэр эрэгтэй өрөөн өсөрч ядараб. DEM $1^{\text {st }}$.masc.sg himself dance tired-PAST 'He danced himself tired.'}

During the process of CHANGE-OF-STATE EVENT, the FOCUS moves from the ACTION (V1) to THE RESULT (V2), i.e. the ACTION (өсөрч) recedes into the background, while the RESULT (ядараб) is brought into the foreground. As a result, decausativisation occurs, c.f. (27):

(27) the process of decausativisation:

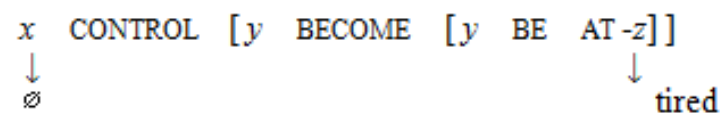

Anticausativisation seems impossible in adjective-post resultatives, as illustrated in (28).

$\begin{array}{cclcl}\text { (28) a. Тэр } & \text { эрэгтэй } & \text { төмөр } & \text { таяг } & \text { дабдажъ } \\ \text { DEM } & 1^{\text {st. }} \text {.masc.sg } & \text { metal } & \text { stick } & \text { pound } \\ \text { yрт } & \text { болгаб. } & & \\ \text { long } & \text { РАST } & & \\ \text { b. Tэp } & \text { эрэгтэй } & \text { ль сийг сажилажъ сэргээб. } \\ \text { DEM } & 1^{\text {st. }} \text {.masc.sg } & \text { Lisi } & \text { shake awake-PAST }\end{array}$

The failure of anticausativisation in adjective-post resultatives lies in the fact that the ACTION verbs (дабдажь 'pound' (28a); сажилажъ, 'shake' (28b)) denote MANNER and imply a strong agency. The patient cannot therefore be identified by the agent.

Moving on to adjective-initial Resultatives $\left[\mathrm{NP}_{1} \mathrm{AP} \mathrm{V}_{\mathrm{t}}\right.$ $\mathrm{NP}_{2}$ ], these can be understood as ' $\mathrm{x}$ ACT ON $\mathrm{y}$, until $\mathrm{y}$
BECOME $z^{\prime}$, where the adjective behaves like an adverbial. ${ }^{3}$ This type of construction is described in (29):

(29).

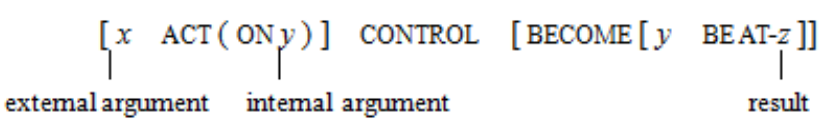

Illustrations of this type are provided in (30)-(32):

(30). Тэр эрэгтэй гутлаа цоортол өмссөн. DEM $1^{\text {st }}$.masc.sg shoe broken wear-PAST 'He wore the shoes (until they were) broken.'

(31). Тэр эрэгтэй архийг дуустал нь уусан. DEM $1^{\text {st }}$.masc.sg pub empty drink-PAST

'He drank the pub empty.'

(32). Тэр эмэгтэй үсээ хар өнгөөр будсан. DEM $1^{\text {st }}$.femi.sg hair black colour dye-PAST 'She dyed her hair black.'

Adjective-initial resultative constructions like (32) can identify the agent and patient, leading to anticausativised resultatives, as in (33):

(33). Үсээ хар өнгөөр будсан. (anticausativisation) hair black colour dye-PAST 'The hair has been dyed black.'

The process of anticausativisation of 'Үсээ хар өнгөөр будсан' would be:

(34).

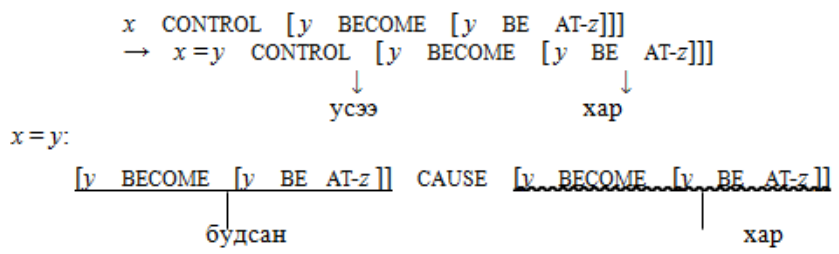

Regarding co-verb resultatives, V1 indicates the ACTION; V2 conveys the RESULT. V1 can be an unergative verb, unaccusative verb, or transitive verb; V2 can be an unaccusative verb or an unergative verb. The argument structure has the following variations:

(35). (I) [Transitive + Unaccusative];

(II) [Unergative + Unaccusative]; or

(III) [Unergative +Unergative].

As touched on earlier, one of the significant roles played by co-verb resultatives is to render derived resultatives, as shown in (36). It may also convey inherent resultatives, as in (37).

3 Mongolian linguist Ce Rima (2007) names it “状述结构, (adverb-predicate structure). 
(36). Derived resultatives:
a. Тэр эрэгтэй үсээнбййрэн
DEM $1^{\text {st }}$. masc.sg pen
бичиж байгаад хугалсан. ${ }^{4}$
write-break-PAST
He uses (writes) the pen (until it is) broken.
b. Тэр эмэгтэй ханаа улаанаар будсан. DEM $1^{\text {st }}$.femi.sg wall red.INSTR paint-PAST 'She painted the wall red.'

(37). Inherent resultatives:
a. Тэр эрэгтэй хаалга dem 1st.masc.sg door 'He pushed the door open.'
онгойлгосон. push-open-past
b. Хаалга онгойсон. door push-open-past
'The door opened.'

Moreover, both anticausativisation and decausativisation can be licensed by co-verb resultatives, as exemplified by (38) and (39).

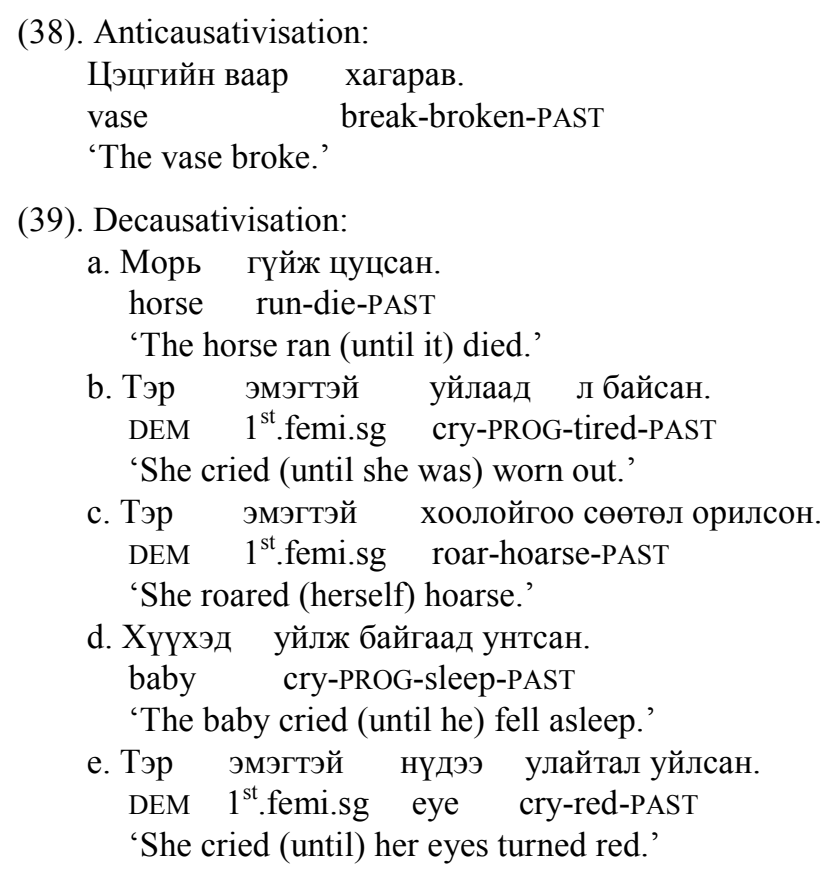

So far, three types of Mongolian resultatives, (a) adjective-post types, (b) adjective-initial types, and (c) co-verb types, have been demonstrated in the light of the 'lexical conceptual structure'. It has been observed that decausativisation is welcome in adjective-post types, and that anticausativisation is realised in adjective-initial resultatives. The significant role of the co-verb type is to fill the gap of ACTION and RESULT in derived resultatives.

4 A typological issue is how to identify grammatical category cross-linguistically. Croft (1990) names this the problem of cross-linguistic comparability. He argues that semantic and functional criteria are the best solution to this problem. байгаад in (55a) and улаанаар in (55b) are unaccusative verbs.

\subsection{Adjective Distribution in Mongolian Resultatives}

Having drawn a picture of Mongolian resultatives, this section delves into adjective distribution. The discussion will focus on resultatives and direct perception expressions.

As a starting point, we drew a list of the most-used adjectives in Mongolian from the corpus:

(40) эцсэн (tired) / гүн (deep) / урт (long) / хатуу (hard) / нүцгэн (naked) / үхсэн (dead) /

өвчин (sick) / чийг (wet) / хавтгай (flat) / сэріїн

(awake) / хоосон (empty)

The concept of 'scale structure' is adopted to measure their scalar property. The modifiers жинхэнэ ('very') and xazac ('half') helped with the diagnosis. Three Mongolian native speakers provided the judgements. The results are summarized in (41).

\begin{tabular}{|c|c|c|}
\hline \multicolumn{3}{|l|}{ (41). а. жинхэнэ (very) } \\
\hline жинхэнэ чийг & (very wet) & [natural] \\
\hline жинхэнэ эисэн & (very tied) & [natural] \\
\hline жинхэнэ г гүн & (very deep) & [natural] \\
\hline жинхэнэ $y p m$ & (very long) & [natural] \\
\hline жинхэнэ хатуy & (very hard) & [natural] \\
\hline * жинхэнэ өвчин (ve & y sick) & icceptable] \\
\hline ? жинхэнэ хавтгай & (very flat) & [unnatural] \\
\hline ? жинхэнэ нүигэн & (very naked) & [unnatural] \\
\hline жинхэнэ $\quad$ хсээн & (very dead) & [natural] \\
\hline жинхэнэ сэрүҮн & (very awake) & [natural] \\
\hline жинхэнэ хоосон & (very empty) & [natural] \\
\hline b. xazac (half) & & \\
\hline хагас чийг & (half wet) & [unnatural] \\
\hline ? хагас эиссэн & (half tied) & [unnatural] \\
\hline хагас $2 Y^{H}$ & (half deep) & [natural] \\
\hline ? хагас урm & (half long) & [unnatural] \\
\hline ? хагас xamyy & (half hard) & [unnatural] \\
\hline ? хагас өвчин & (half sick) & [unnatural] \\
\hline ? хагас хавтгай & (half flat) & [unnatural] \\
\hline ? хагас нүицгэн & (half naked) & [unnatural] \\
\hline ? хагас $ү x с э н$ & (half dead) & [unnatural] \\
\hline хагас сэруүн & (half awake) & [natural] \\
\hline ? хагас хоосон & (half empty) & [unnatural] \\
\hline
\end{tabular}

Building on this, we arrived at a four-layer classification of Mongolian adjectives:

(42). a. Totally open-scale: эисэн (tied), урт (long), гүн (deep)

b. Lower closed-scale: чий (wet), өвчин (sick),
өлөссэнийг (hungry),
хусугсанийг (shaved)
c. Upper closed-scale: $x$ хтуу (hard), сэрҮYн (awake),
чайсанийг (pale)
d. Totally closed-scale: нүцгэн (naked), үхсэн (dead), хоосон (empty), хавтгай (flat) 
In light of the classification, the following section tackles the adjectives distribution. Investigation starts from resultative construction. Tests along with the four different scalar structures of APs are carried out, c.f. (43)-(45). Native speakers again assessed the examples.

(43). Totally open-scale AP

a. жан сан: төмөр таяг дабдажъ урт болгаб. Zhang san metal stick pound long PAST 'Zhang san pounded the metal long.'

b. жан сан: өрөөн өсөрч ядараб. Zhang san himself dance tired.PAST 'Zhang san danced himself tired.'

(44). Lower closed-scale AP

a. жан сан: өрөөн иниесээр байжъ

Zhang san himself laugh PROG

Өбчитай болоб.

sick PAST

'Zhang san laughed himself sick.'

?b. жан сан: өбөст газар усулжъ чийг болгаб.

Zhang san garden water wet PAST

'Zhang san watered the garden wet.'

(45). Upper-closed scale AP

*a. жан сан: ус хӨ $\Theta^{5}$ лдээжъ хатуу болгаб.

Zhang san water BA freeze solid PAST

'Zhang san froze the water solid.'

b. жан сан: ль сийг сажилажъ сэргээб.

Zhang san Li si shake awake.PAST

'Zhang san shook Li si awake.'

(46). Totally closed-scale AP

? а. жан сан: төмөр таяг дабдажь

Zhang san metal stick pound

хабтагай болгаб.

flat PAST

'Zhang san pounded the metal flat.'

b. *Нуур хатуу_биет хөлджээ.

lake solid freeze.PAST

'The lake froze solid.'

Perhaps we may arrive at several layers illustrating the acceptability thresholds of Mongolian APs in resultatives, running from 'Totally open-scale $\mathrm{AP}$ ' down to 'Lower closed-scale AP', 'Upper-closed scale AP', 'Totally closed-scale AP'.

\subsection{Adjective Distribution in Direct Perception Expressions}

Now we are in the position of engaging in the analysis of adjectives in direct perception expressions. Tests along with the various scalar properties of Mongolian adjectives were carried out and again data were assessed by the native speakers.

$5 \mathrm{x} \Theta$ is a co-verb.
(47). Totally open-scale AP

жан сан лъ сийн ядарагсанийг Үзэб.

Zhang san $\mathrm{Li}$ si tired see.PAST

'Zhang san saw Li si tired.'

(48) Totally closed-scale AP
а. жан сан нохойн ҮхҮгсэнийг Үзэб. Zhang san dog dead see.PAST
'Zhang san saw the dog dead.'
b. жан сан ль сийн нүщгэн нь олжъ үзэб. Zhang sanLi si naked see.PAST
'Zhang san saw Li si naked.'

(49) Upper closed-scale AP

$\begin{array}{lllr}\text { жан сан ль сийн } & \text { чайсанийг } & \text { Үзэб. } \\ \text { Zhang san Li si } & \text { pale } & \text { see.PAST } \\ \text { 'Zhang san saw Li si pale.' } & & \end{array}$

(50) Lower closed-scale AP
а. жан сан лъ сийн өлөссэнийг үзэб. Zhang san Li si hungry see.PAST
'Zhang san saw Li si hungry.'
b. жан сан ль сийн хусугсанийг үзэб. Zhangsan Li si shaved see.PAST 'Zhang san saw Li si shaved.'

The finding brings us to the point that Mongolian welcomes all layers of adjectival complements in direct perception expressions.

\subsection{Summary}

To summarise, Mongolian resultatives are of three types: (i) adjective-post resultative $\left[\begin{array}{lllll}\mathrm{NP}_{1} & \mathrm{~V} & \mathrm{NP}_{2} & \mathrm{AP}\end{array}\right]$, (ii) adjective-initial resultative $\left[\begin{array}{llll}\mathrm{NP}_{1} & \mathrm{AP} & \mathrm{V} & \mathrm{NP}_{2}\end{array}\right]$, and (iii) co-verb resultative $\left[\begin{array}{lllll}\mathrm{NP}_{1} & \mathrm{~V} & \mathrm{~V} & \mathrm{NP}_{2}\end{array}\right]$. Adjective-initial resultatives can be understood as ' $\mathrm{x}$ ACT ON $\mathrm{y}$, until $\mathrm{y}$ BECOME $z$ ', where the adjective behaves like an adverbial. Decausativisation is tolerated by adjective-post resultatives, while anticausativisation is ruled out. Anticausativisation can be realised in adjective-initial resultatives.

The acceptability of Mongolian APs in resultatives runs from 'Totally open-scale AP' down to 'Lower closed-scale AP, Upper-closed scale AP, Totally closed-scale AP'. Moreover, Mongolian welcome all layers of adjectival complements in direct perception expressions.

\section{Adjective Distribution in Japanese}

Having drawn a picture of the sensitivity of APs in Mongolian, we are in a better position to engage in the analysis of Japanese data. Our starting point is the scalar property of adjectives.

\subsection{Adjectives in Resultatives}

Traditionally, Japanese adjectives are divided into two 
groups, i.e. $i$-adjectives (c.f. 51) and $n a$-adjectives (c.f.52).

\section{(51). (i-adjective)}

Taroo wa gomu o nagaku nobashita.

Taroo TOP rubber ACC long stretch.PAST

'Taroo stretched the rubber long.'

(52). (na-adjective)

John ga musuko o joobu ni sodateta.

John NOM son ACC tough COP bring up.PAST

'John brought up his son; his son turns out to be tough.'

(Examples are taken from Uegaki 2009)

This study reclassifies Japanese adjectives into two types, open-scale adjectives and closed-scale adjectives. The predicate of an open-scale adjective is 'ku', e.g. takai $\rightarrow$ takaku. The predicate of a closed-scale is 'ni', e.g. massugu $\rightarrow$ massugu ni. Examples (51) and (52) represent illustrations of resultatives rendered by open-scale adjectives (51) and resultatives conveyed by closed-scale adjectives (52).

It thus appears that both open-scale adjectives and closed-scale adjectives are possible to render a result in Japanese. Nonetheless, the two types of adjectives represent distinct lexicalisations. The resultatives rendered by an open-scale adjective usually have no endpoint. The closed-scale adjectives constantly co-occur with the copular $n i$. The adjectival complement and the copula $n i$ together form the resultative complement. The Japanese copular $n i$ is a closed-scale morpheme. Thus, the constructions rendered by closed-scale adjectives involve a CHANGE-OF-STATE that entails an endpoint. Adjectival predicates, along with their lexical representations, are summarised in Table 2.

Table 2. Japanese adjectival predicates along with their lexical representations

\begin{tabular}{|c|c|c|}
\hline AP & Scalar Property & $\begin{array}{c}\text { Lexical } \\
\text { Representation }\end{array}$ \\
\hline$i$-adjective & Open-scale & $\mathrm{AP} \mathrm{V}_{\text {resultative path }}$ \\
\hline$n a$-adjective + copula $n i$ & Closed-scale & $\begin{array}{c}\mathrm{CP}_{\text {resultative path }} \\
\mathrm{V}_{\text {manner of action }}\end{array}$ \\
\hline
\end{tabular}

Another important issue to be addressed is that the above constructions are all inherent resultatives. Derived resultatives are missing in Japanese; neither an adjective nor a postpositional phrase is possible to render a derived result, as in (53):

\section{(53). Derived Resultatives in Japanese}

*Kanojo wa sakana o zerii joo ni
She TOP fish ACC jelly DAT
tataita.
pound.PAST
'She pounded the fish to a jelly.'

The reason why Japanese lacks derived resultatives can be explained the same way as for Mongolian: derived resultatives can only be conveyed by compound verbs, as shown in (54).
(54). Derived resultatives by compound verb

Hanako wa sakana o zerii joo ni
Hanako TOP fish ACC jelly DAT
tatakitubushita.
smash-pound. PAST
'Hanako pounded the fish to a jelly.'

\subsection{Adjectives in Direct Perception Expression}

Two perceptual verbs are often seen in Japanese direct perception expressions, i.e. 見える mieru and 見るmiru. mieru is an unaccusative verb and means that a certain view leaps to the eyes. The subject is often denoted by a scene or an inanimate lexicon. In fact, the subject of the unaccusative verb mieru is actually the object of the transitive verb 見る miru. The subject of miru is the observer, often rendered by animate lexicons. Crucially, miru delivers a pure perceived event and is therefore incapable to fulfil a metaphorical interpretation. The unaccusative verb 見える， along with model verbs such as ように (c.f. 〜ように見え る), or via an auxiliaryそうに (c.f. 〜 そうに見える), may convey a metaphorical interpretation, in which case the subject of mieru can be animate or inanimate. Bearing this in mind, we move on to examine how adjectives distribute in Japanese direct perception expressions. First, open-scale APs appear to be licensed, as illustrated in (55):

(55). Direction perception expression rendered by open-scale APs:

Aki wa sora ga tooku mieru.
fall TOP sky NOM distance
'In fall, the sky appears high.'

More illustrations are provided in (56):

(56). Direction perception expression rendered by open-scale AP:

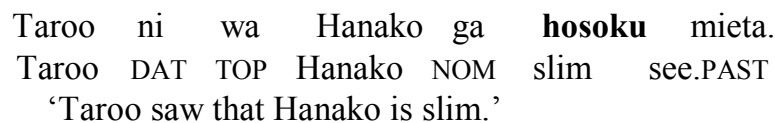

(Takezawa 2011)

The perception verb mieru indicates an evaluation of the scene, i.e. the sub clause 'Hanako ga hosoi (Hanako is slim)'. Note that the proposition can be false. After all, it is an evaluation by the observer, not a truth. In (56), it can have the following interpretation: Hanako is actually fat, but from Taro's point of view, Hanako is slim. In this regard, mieru is somehow subjective. Its transitive partner, miru ('to see'), fails to appear in this expression, as miru simply renders a true scene.

Not only open-scale APs are licensed: closed-scale APs are also welcomed in Japanese direct perception expressions, as illustrated in (57): 
(57). Direction perception expressions rendered by resultative constructions. closed-scale APs:

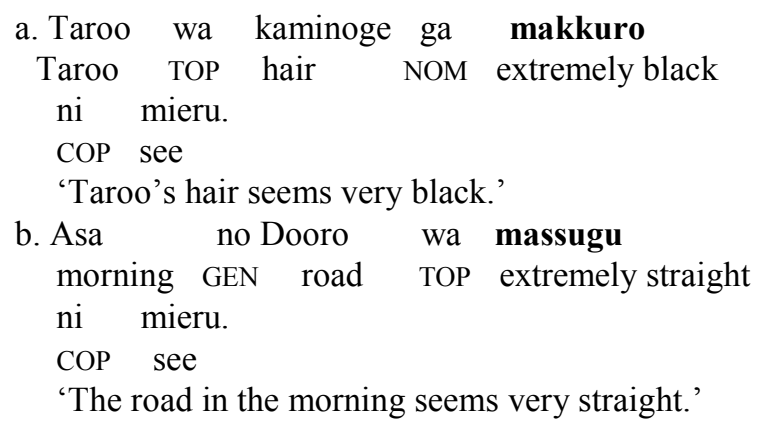

Bear in mind that $n i$ in (57) functions as a copular. The AP-complement and the copula $n i$ together form the perceptual complement. This is exactly the same as $n i$ in

\section{Summary}

This paper has explored the adjective distribution of two Altaic languages, Mongolian and Japanese. The findings can be summarised as follows.

Mongolian resultatives are of three types, i.e. adjective-post resultative; adjective-initial resultative; co-verb resultative. Among them, decausativisation is welcome by adjective-post type; anticausativisation is realised in adjective-initial resultatives. The co-verb type plays the part of rendering derived resultatives. This is summarised in Table 3.

Table 3. Mongolian resultative types

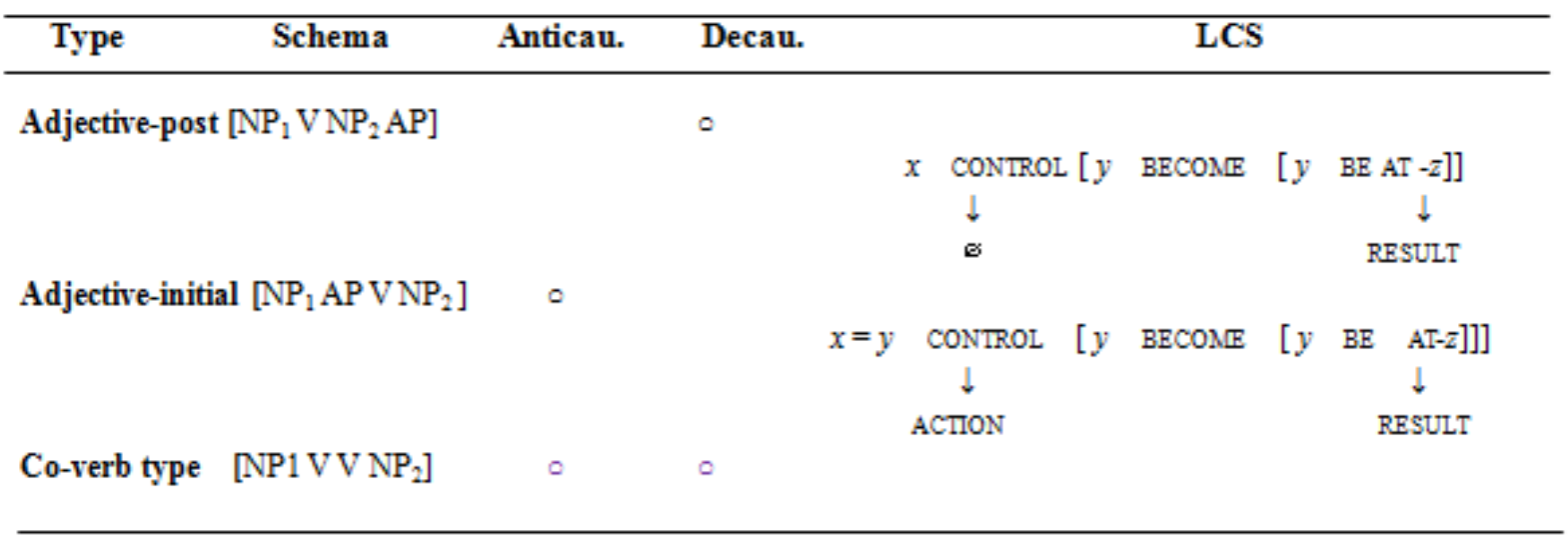

Table 4. Mongolian adjectives in resultative and direct perception constructions

\begin{tabular}{lccc}
\multicolumn{1}{c}{ Scalar property } & $\begin{array}{c}\text { inherent resultatives } \\
\text { high }\end{array}$ & $\begin{array}{c}\text { derived resultatives } \\
\text { Totally open scale }\end{array}$ \\
Lower closed scale & & $\times$ & Direct perception expression \\
Upper closed scale & $\downarrow$ low & $\times$ & $\circ$ \\
Totally closed scale & & & $\circ$ \\
\hline
\end{tabular}


Mongolian only tolerates inherent resultatives; derived resultatives are ruled out. The acceptability of adjectival complements in inherent resultatives runs from 'Totally open-scale AP' down to 'Lower closed-scale AP, Upper-closed scale AP, Totally closed-scale AP'. On the other hand, adjectival complements in direct perception expressions are of no diverse acceptability, i.e. all layers of APs appear to be licensed. This is summarised in Table 4 .

This study proposed two types of Japanese adjectives, i.e. open-scale adjectives (corresponding to $i$-adjective) and closed-scale adjectives (corresponding to $n a$-adjective). The two types of adjective are capable of rendering an inherent result. However, like Mongolian, derived resultatives are ruled out in Japanese. Furthermore, inherent resultatives rendered by open-scale adjectives and closed-scale adjectives present different lexicalization patterns. The resultatives rendered by an open-scale adjective usually have no endpoint. Closed-scale adjectives, on the other hand, may involve a CHANGE-OF-STATE that entails an endpoint.

Regarding direct perception expressions, it seems that Japanese welcomes both open-scale and closed-scale APs. Moreover, there are two perceptual verbs, 見るmiru (transitive) and 見える mieru (unaccusative). 見る miru solely delivers the perceived event and is thus deemed objective. 見える mieru, on the other hand, cannot fulfil a metaphorical interpretation, and appears to be subjective.

Finally, the lack of derived resultatives in Altaic language family is explained by the fact that Altaic languages are likely to lexicalise the RESULT into the MAIN VERB. In inherent resultatives, there is a connection between the CAUSE EVENT [EVENT 1 x ACT ON $y$ ] and the RESULT EVENT [EVENT $2 y$ BECOME Z]. To put it another way, the CONTROL part of LCS carries an implication of $z$. In derived resultatives, however, the ACTION fails to lead directly to the RESULT; a GAP thus arises between the ACTION and the RESULT.

\section{Acknowledgements}

This paper is based on work that was supported by the National Foundation of Social Sciences (15CYY002) to Wenchao Li.

\section{REFERENCES}

[1] Boas, Hans C. 2000. Resultative constructions in English and German. Doctoral Dissertation. Chapel Hill: University of North Carolina.

[1] Boas, Hans C. 2003. A Constructional Approach to Resultatives. CSLI Publications. Stanford.
[2] Ce Rima. 2007. Adverb-predicate structure: comparison with Chinese. Thesis of Northeast University of China.

[3] Chomsky, Noam. 1965. Aspects of the Theory of Syntax. Cambridge, MA: MIT Press.

[4] Croft, William. 1990. A conceptual framework for grammatical categories (or: a taxonomy of Propositional Acts). Journal of Semantics 7(3). 245-279.

[5] Dimitrova-Vulchanova Mila. 2002. On two types of results: resultatives revisited. Ms NTNU Trondheim.

[6] Goldberg, Adele. 1995. Constructions: A Construction Grammar Approach to Argument Structure. Chicago: University of Chicago Press.

[7] Iwata, Seizi. 2006. Argument Resultatives and Adjunct Resultatives in a Lexical Constructional Account. Language Sciences 28: 449-496.

[8] Jackendoff. Ray. Semantic structures. The MIT Press, 1990.

[9] Kageyama, Taro. 1996. Doushiimiron-gengo to ninchi no setten. Kuroshio.

[10] Kageyama, Taro. 1999. Word formation. In The Handbook of Chinese Linguistics (ed.). Natsuko Tsujumura. Malden, MA: Blackwell Publishers.

[11] Kennedy, Christopher. 1999. Projecting the Adjectives: The Syntax and Semantics of Gradability and Comparison. New York: Garland.

[12] Kennedy, Christopher \& Louise McNally. 2005. Scale structure, degree modification, and the semantics of gradable predicates. Language 81. 2, 345-381.

[13] Levin, Beth and Rappaport Hovav. 1995. Unaccusativity, MIT Press, Cambridge, MA.

[14] Levin, Beth. \& Rappaport Hovav. 2010. Lexicalized scales and verbs of scalar change. Paper presented at the CLS 46.

[15] Rappaport Hovav and Beth Levin. 1998. Building Verb Meanings. In M. Butt and W. Geuder (ed.). The Projection of Arguments: Lexical and Compositional Factors, CSLI Publications, Stanford, CA, 97-134.

[16] Tsujimura, Natsuko. 2001. A constructional approach to stativity in Chinese. Studies in Language 25.3, 525-553.

[17] Washio, Ryuichi. 1997. Resultatives, compositionality, and language variation. Journal of East Asian Linguistics 6:1-49.

[18] Wechsler, Stephan. 2000. An Analysis of English Resultatives under the Event-Argument Homomorphism Model of Telicity. In Proceedings of the 3rd Workshop on Text Structure, University of Texas, Austin.

[19] Wechsler, Stephan. 2005. Resultatives under the 'event-argument homomorphism' model of telicity. In Nomi Erteschik-Shir \& Tova Rapaport (ed.). The syntax of aspect. Oxford: Oxford University Press. 255-274.

[20] Wyngaerd, Guido Vanden. 2001. Measuring events. Language 77.1, 61-90. 